\title{
Academic Drift in Dutch Non-University Higher Education Evaluated: A Staff Perspective
}

\author{
Author(s) \\ Griffioen, D.M.E.; de Jong, Uulkje \\ DOI
}

10.1057/hep.2012.24

Publication date

2013

Document Version

Submitted manuscript

Published in

Higher Education Policy

Link to publication

Citation for published version (APA):

Griffioen, D. M. E., \& de Jong, U. (2013). Academic Drift in Dutch NonUniversity Higher Education Evaluated: A Staff Perspective. Higher

Education Policy, 26(2), 173-191. https://doi.org/10.1057/hep.2012.24

It is not permitted to download or to forward/distribute the text or part of it without the consent of the author(s) and/or copyright holder(s), other than for strictly personal, individual use, unless the work is under an open content license (like Creative Commons).

\section{Disclaimer/Complaints regulations}

If you believe that digital publication of certain material infringes any of your rights or (privacy) interests,

please let the Library know, stating your reasons. In case of a legitimate complaint, the Library will make the material inaccessible and/or remove it from the website. Please contact the library:

https://www.amsterdamuas.com/library/contact/questions, or send a letter to: University Library (Library of the University of Amsterdam and Amsterdam University of Applied Sciences), Secretariat, Singel 425, 1012 WP Amsterdam, The Netherlands. You will be contacted as soon as possible. 


\title{
Academic Drift in Dutch Non-University Higher Education Evaluated: A Staff Perspective
}

\author{
D.M.E. (Didi) Griffioen ${ }^{\mathrm{a}}$ and U. (Uulkje) de Jong ${ }^{\mathrm{b}}$ \\ ${ }^{a}$ Staff Department Education and Applied Research, Amsterdam University of Applied Sciences, \\ Spui 25, room 1.19, Amsterdam, 1012 WX, The Netherlands. \\ E-mail: D.M.E.Griffioen@hva.nl \\ ${ }^{\mathrm{b}}$ Department of Education, University of Amsterdam, Amsterdam, The Netherlands. \\ E-mail: U.dejong@uva.nl
}

In the context of a European knowledge economy, the Dutch non-university institutions systematically develop research activities at a higher frequency than before. With this development, they have been accused of academic drift, of striving to receive a status comparable to traditional universities. This study considers the perceptions of both managers and lecturers in non-university higher education concerning the organisational aims for research activities. The intention is to add an empirical base to the debate of academic drift, especially to the potential of academic drift on the staff level. The results show a moderate indication of potential for academic drift on the staff level. In addition, managers have more positive perceptions regarding all aims for research than lecturers, but both groups prioritise that the results of research should, first and foremost, be directed towards improving the quality of education.

Higher Education Policy advance online publication, 16 October 2012; doi:10.1057/hep.2012.24

Keywords: academic drift; non-university; vocational; innovation; research policy

\section{Introduction}

Academic drift is a concept used to describe academisation processes of nonuniversity educational institutions. Although it has a longer and wider tradition (Neave, 1978, 1979), the concept of academic drift was used to analyse the tendency of the Polytechnics in the United Kingdom to develop activities comparable to traditional universities at the end of the 20th century, followed by various comparable developments in other European countries (Teichler, 2008; Kyvik, 2009). With the Bologna Declaration in 1999, new policy lines were formulated in the light of the global economy, which resulted in changed demands on the professionals of the 21st century and a more uniform system of qualifications between university and non-university higher education (Teichler, 2008). The new demands also suggested that professionals should be trained 
more in research activities, enabling them to apply and update innovative knowledge in their work context (Brew, 2010).

As a result, in several European countries, non-university institutions of higher education were expected to become hybrid institutions of research and teaching; before this, they were teaching institutions only. Formally, the new research activities introduced the non-university institutions of higher education into the domain of the traditional universities (Kyvik and Skodvin, 2003; Kyvik, 2004; Mudde, 2005; Teichler, 2008; Witte et al., 2008). In this process, the Dutch traditional universities showed a territorial attitude, thinking these new activities would result in the end of the binary system of higher education as well as the end of their monopoly of the research grants of the government (Huisman and Kaiser, 2001; Griffioen and De Jong, 2007; Lepori and Kyvik, 2010). The non-university institutions, on the other hand, acted from a strategy of accentuating their differences from the traditional universities, while striving for equal status (Teichler, 2008; Lepori and Kyvik, 2010).

This article empirically investigates the potential for academic drift at the staff level in the Dutch non-university institutions of higher education by studying the preferences of lecturers as well as managers regarding the aims for research at their institutions. And even though individual research preferences and organisational or teaching actions are only loosely related (see also Visser-Wijnveen et al., 2009), the preferences of lecturers and managers may indicate the orientation for institutions of non-university higher education. Further, this article will look at the perceived effects of research activities to indicate actual academic drift in the institutions. This study therefore adds an empirical base to the more emotional debate on academic drift.

\section{Academic Drift in Dutch Non-University Institutions}

The Dutch system of higher education, the context of this study, has a binary structure that consists of 14 traditional and technical universities (here collectively called 'traditional universities') and just over 40 institutions of higher vocational education (called hogescholen) ${ }^{1}$ (de Boer et al., 2007; Huisman, 2008; de Weert and Leijnse, 2010). The latter type of institutions, which are somewhat comparable to the former British polytechnics and the German Fachhochschulen, call themselves 'Universities of Applied Sciences' (UAS) (Teichler, 2008; Vogel, 2009; de Weert and Leijnse, 2010).

The concept of academic drift is mostly described as the attempt of nonuniversity institutions to strive for an academic status, recognition, and rights associated with university institutions in an upward movement to resemble the university (Kyvik, 2007; Teichler, 2008; Christensen and Erno-Kjolhede, 2011). Neave (1979) describes academic drift as a departure from a series of publicly 
stated and accepted objectives in which academic and theoretical work are opposed to the development of the vocational side. Harwood (2010) defines these objectives as universities being more 'science-oriented' and nonuniversities being more 'practice-oriented', by which the drift of non-university institutions can be considered a shift of educational institutions to become more science-oriented and less practice-oriented. On the basis of a division by Neave (1979) into three analytic levels of academic drift, Kyvik (2007) describes six different, though related, academic processes: student drift, staff drift, programme drift, institutional drift, sector drift, and policy drift. The remainder of this section describes the Dutch situation and its debate on academic drift in non-university education through the six processes of academic drift defined by Kyvik (2007).

\section{Policy drift}

Non-university institutions of higher education were defined as a separate level of secondary education from the 1960s onward. The Dutch institutions for higher vocational education have been primarily teaching institutions (Huisman, 2008). Conducting research to improve the individual professions has been allowed by law since 1986 (WHBO) when the hogescholen were placed outside the system of secondary education. But aside from a few contract-research activities, these activities occurred only in the final years of the curricula, and as an activity of lecturers separate from the educational programmes. With the introduction of the Higher Education Act (WHW) in 1992, the higher vocational educational programmes became formally part of the higher education system (Huisman, 2008; de Weert and Leijnse, 2010). Therefore, state authorities have slowly but surely adjusted their expectations for the institutions of non-university higher education: from being part of secondary education towards being part of the higher educational system, including research-related tasks, which can be considered policy drift (Kyvik, 2007). These researchrelated tasks were supposed to help educate a new kind of professionals who would be able to apply and update innovative knowledge in their work context (Brew, 2010). The Dutch government considered the hogescholen essential to fulfil this task (Dutch Ministry of Education Culture and Science and Netherlands Association of Universities of Applied Sciences, 2001).

\section{Student drift as a necessity}

An increase in the number of students has influenced the presence of policy drift in the higher educational system from the 1960s onward (see Figure 1), partly due to the government's open-door policy for higher education. Traditional universities were not able to cope with the influx because of the tradition 


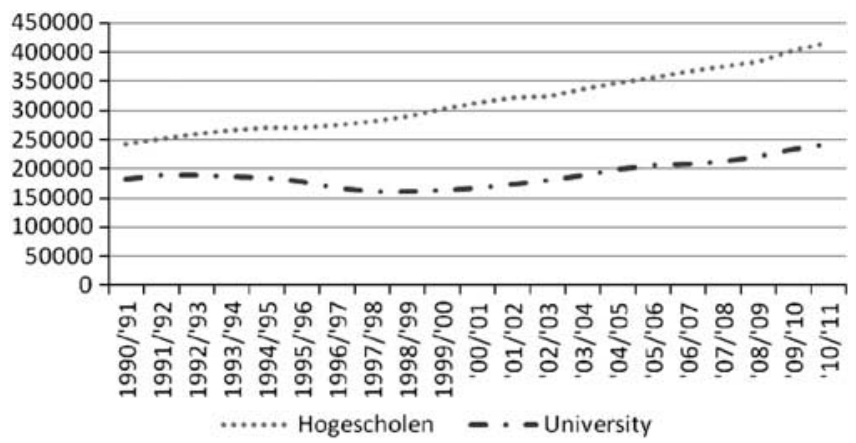

Figure 1. Number of students in Dutch hogescholen and universities (based on (http:// statline.cbs.nl/StatWeb/publication/).

of research-intensive education, which was a costly, small-scale type of education (Rupp, 1997; Baggen, 2005; Teichler, 2008). In addition to several diversifying adjustments to the traditional university system (Baggen, 2005), the Dutch hogescholen became a new, less expensive part of the higher educational system. In other words, they were made more equal to the traditional universities than before (Huisman, 2008; Teichler, 2008). Nowadays, the Dutch hogescholen account for more than $60 \%$ of all Dutch students in higher education.

The general increase of students in the total system of higher education during the 20th century can be considered as student drift (Kyvik, 2007). Still, when looking at the relative numbers of students between non-university and university education in Figure 1, both slopes seem parallel. Thus, on the aggregate level, there is no indication of student drift from non-university to university higher education.

\section{Implementing research tasks: Sector, institutional, and programme drift}

The European policy drift around the Bologna Declaration in 1999 resulted in a treaty between the Dutch Minister of Education and the hogescholen (2001), by which new research-related tasks were defined for all hogescholen on top of their teaching tasks:

1. To raise the quality of the educational programmes and the quality of the teaching staff.

2. To add to the theoretical body of knowledge of the different professions.

3. To help the professional field to innovate. 
The legal status of research activities in the hogescholen remained based on the law of 1992 (WHW): 'Hogescholen [..] can carry out design and development activities or research directed to the professional field [..]'. The possibility of public funding was added to initiate research-related activities. Previously, formal entry into the system of higher education research was almost non-existent in the non-university institutions and no structural means for it were present, whereas research activities are central to the identity of the traditional universities (Witte et al., 2008). Also, in the non-university institutions, research skills or experience usually constitute no ground for selection in the application procedures for lecturers (Kyvik and Skodvin, 2003; de Jong and de Jager, 2007), since professional and didactic skills were seen as most necessary for educating professionals. Large groups of lecturers had professional bachelor's degrees as their highest formal qualification (Dutch Ministry of Education Culture and Science, 2011). Even recent estimates imply that, on average, academic staff in hogescholen spend only about $8 \%$ of their time on research activities (Huisman, 2008). All this has led to a situation today in which most of these institutions lack a research culture (Huisman, 2008; van der Linden et al., 2012).

The character of the new research activities was supposed to be practical rather than science-oriented, with research questions directed towards solving problems derived from the practical domain and adding to the educational programmes (Advisory Council for Science and Technology Policy, 2005; Harwood, 2010). Sector-wide, professional researchers (lectoren) were introduced as carriers of the new research-related tasks to develop and circulate (new) knowledge (Lepori and Kyvik, 2010). Having a master's or Ph.D. became a criterion in selection procedures for lecturers (in addition to professional experience). A sector-wide system for evaluating research quality was developed (VKO, 2010).

On the institutional level, most institutions created research and development groups (kenniskringen) consisting of one or more professional researchers combined with several lecturers. Programmes to allow lecturers to study for a master's degree or a Ph.D. were also introduced (further indicating staff drift), and many networks, mostly regional, were established between professors and external companies with evidence-based innovation as the main objective (Huisman, 2008).

At the programme level, research skills were implemented as part of the final qualifications. Some of these qualifications were based on the Dublin Descriptors (http://www.nuffic.nl/nederlandse-organisaties/informatie/internat ionaliseringsbeleid/bolognaproces/achtergrondinformatie/drie-cycli/dublindesc riptoren), but often the more advanced goal of qualifying the students to conduct (practical) research was added. 


\section{Fear of academic drift}

Indication of changes can be found on all levels, but the expressed fear of academic drift in the public debate after the Treaty of 2001 is mainly directed to the sector level (see also Griffioen and de Jong, 2007). In public debates, the hogescholen are accused of wanting to conduct research similar to the research activities of the traditional universities, by (a) choosing similar aims for research, such as improving the practical field by research results; and (b) practising similar methods of research, such as practice-based types of research (Dijstelbloem and Schuyt, 2003; Advisory Council for Science and Technology Policy, 2005; Duursma, 2005; Leijnse, 2005a; Mudde, 2005).

Improving the quality of their own educational programmes and teaching staff through research is not an aim of the traditional universities (who usually direct research towards adding to the general body of knowledge) (Leijnse, 2005b; van Lieshout and Borgdorff, 2005). Hence, if research at the hogescholen were to be directed towards improving their own educational programmes, the fear of academic drift would be unnecessary. At the same time, this fear could decrease possibilities to collaborate in research or education. The question is whether or not hogescholen, within the direction of research as agreed on in the Treaty of 2001, choose a more 'scientific' or a more 'practical' approach. The traditional universities state that the aim of the (indirect) improvement (of theory and education) in the professional field cannot be reached, since research in the hogescholen is structured as a standalone activity and not connected to educational tasks (Mudde, 2005).

Another way of evaluating the direction of research towards educational and professional improvement aims is by looking at the perceptions of the employees. Research activities at the hogescholen are of a recent date, so organisational structures are being built. The question is: In which direction do the lecturers and managers of the hogescholen want to develop their research activities and organisations? Do these developments lead to academic drift in the hogescholen? These preferences of lecturers and managers on researchrelated aims, therefore, are central in this study.

\section{Academic Drift in This Study}

This study evaluates academic drift of Dutch hogescholen by looking at the preferences of lecturers and managers for the direction of research by their institutions. As previously explained, the Dutch non-university institutions received a three-goal task with the legal space in which to conduct research: (a) an educational goal; (b) a theoretical goal; and (c) an external goal. Following Harwood (2010), the more 'science-oriented' aims are considered to 
imply a higher potential of academic drift on the staff level, while being more 'practice-oriented' implies a lower potential of academic drift.

The aim to improve the quality of education implies a low indication of academic drift, since it considers research activities that are directed towards improving the traditional teaching task of non-university institutions. On the other end of the range, adding to a theoretical body of knowledge by conducting research is seen as a goal that implies a larger potential for academic drift since this goal is the most science-oriented. Third, innovation in the professional field is considered a new task that does not necessarily imply a potential for academic drift because it is not initially scientific. Therefore, a higher preference towards innovating the professional field is not seen as an indication of academic drift but rather as an extension of the professional teaching task of non-university institutions.

The same order will be used to study how lecturers and managers perceive the effects of research at their institutions. Are the effects of research activities, as perceived by the lecturers and managers, directed towards theoretical aims (indicating academic drift), towards improvement of educational quality (lacking academic drift), or towards innovation in the professional field (indicating an extension of the traditional teaching task, but not indicating academic drift)?

\section{Managers, Lecturers, and Educational Changes}

The staff of non-university institutions in this study is divided into two groups: lecturers (teaching staff) and managers (non-teaching staff related to the primary process). Preferences concerning research aims are studied in both groups. In the Dutch hogescholen, lecturers are at the root of changing non-university higher education into more research-based organisations, since lecturers are the primary connection between the institution and the students (and often the main connection with the professional field) (Griffioen et al., 2013; van den Berg et al., 2000; Runhaar, 2008). Hence, their perceptions and activities will influence the direction and speed with which the proposed goals are reached or resisted (McRoy and Gibbs, 2009). Choices that educational managers make have a larger impact on the organisational conditions in which education takes place (Boerma et al., 2011). Therefore, both managers and lecturers are essential for all educational innovations and for implementing a new primary process. Both being important actors, lecturers, and managers also often have different perceptions on many organisational aspects, with organisational aims being one of them (Peterson and White, 1992). 
D.M.E. (Didi) Griffioen and U. (Uulkje) de Jong

Academic Drift in Dutch Non-University Higher Education Evaluated

8

\section{Perceptions of lecturers}

When defining expectations for lecturers' perceptions concerning the aims of research, the first issue to consider is that the primary loyalty of lecturers is to their profession. In the case of Dutch non-university higher education, this means their first loyalty is their students. Research shows that the loyalty of lecturers is usually less to their school or department, and the loyalty towards the institution takes an even lower place (Seyd, 2000; McRoy and Gibbs, 2009). Second, the implementation of research activities directed towards raising the quality of educational programmes and teaching staff is increasingly affecting the daily routine of lecturers (van den Berg et al., 2000). An important issue is whether lecturers feel their professional identity or role is being threatened by new research activities or whether these activities conflict with what teachers think is right (Geijsel et al., 2001; Beijaard et al., 2004; Hill and Haigh, 2011). The expectation for this study is that the lecturers' preferences in research aims will be directed towards education, since this is closer to their traditional loyalties and identities, rather than showing indications of academic drift.

\section{Employees with management tasks}

While lecturers mostly have knowledge of one educational programme or one department, managers more often consider the national and European trends and policies, and usually see more possibilities for and fewer obstacles to change. Managers are also mostly the ones initiating large-scale changes or laying out the (sub)-institutional maps for implementing national policy changes. Further, managers are usually able to see changes as a possible better future, while lecturers undergo policy innovations and often distrust yet another change process (van den Berg and Sleegers, 1996; McRoy and Gibbs, 2009). Therefore, for this study, it is expected that managers will have a more positive view of the non-educational research aims than lecturers while also showing a similar positive view of the educational aims.

\section{Method}

\section{Research questions}

The current study investigates the potential for academic drift and is limited to the process of staff drift. What are the preferences of lecturers and managers concerning the three aims for research of non-university higher education (indicating degree of potential academic drift on the staff level)? What effects do they perceive of research activities (indicating actual academic drift)? What are the differences between lecturers and managers in this respect? 


\section{Sample}

All employees of six regionally distributed non-university higher education institutions were asked to complete an extensive questionnaire on researchrelated topics, designed by the authors. This research includes only the responses of those who have at least two scores in each scale used and scores on 'gender', 'being a teacher or not', and 'educational level' ( $N=1,826$, lecturers' $N=1,435)$. The respondents who do not have teaching tasks are included only if they engage in management or staff tasks directly related to the management of education (e.g., not related to information technology services). Due to privacy issues, the response ratio remains somewhat unclear (most conservative estimate: $21 \%$ ). We expect the response differences between the institutions mostly to be due to differences in reminder frequencies.

Of the respondents, most are lecturers $(79 \%)$, most are men $(54 \%)$, and most have a university degree $(69 \%)$, of whom $6 \%$ have completed a Ph.D. The range of respondents from each institution is from $8 \%$ to $28 \%$ of the total sample. The mean age is 47 years (range 21-68). A comparison with the national population shows the range of age and gender to be on average (http://www.hbo-raad.nl/hbo-raad/feiten-en-cijfers/cat_view/60-feiten-en-cijfers/ 62-bedrijfsvoering/66-personeel), while the educational level shows a little higher percentage of university degrees and somewhat fewer Ph.D.s than on average in the Dutch educational staff of hogescholen (Dutch Ministry of Education Culture and Science, 2011).

\section{Measures}

All the respondents were asked to react to 10 statements regarding the aims of research at the hogescholen, scored on a 4-point Likert scale ranging from 'very important' $(=4)$ to 'not important' $(=1)$ (for all items, see Table 1). On the basis of these 10 items, three scales have been constructed in accordance with the means of the separate items. These three scales are in line with the three aforementioned tasks given to the new professors: (a) educational task (two items, Cronbach's $\alpha=0.72$ ); (b) theoretical task (four items, Cronbach's $\alpha=0.75$ ); and (c) external task (four items, Cronbach's $\alpha=0.73$ ).

On the basis of another set of 10 statements, data on the effects of research that the respondents perceive in their own institutions were gathered, out of which three scales have been constructed: (a) educational effects (two items, Cronbach's $\alpha=0.85$ ); (b) theoretical effects (four items, Cronbach's $\alpha=0.86$ ); and (c) external effects (four items, Cronbach's $\alpha=0.86$ ). For tasks and effects, the item 'bring new knowledge to education' statistically shared more variance with the theoretical scales ('knowledge' part of the item) than with the 'education' scales. Therefore, this item was added to the scale of theoretical 
Table $1 \mathrm{M}$ and SD of observed variables and scales

TASKS: My institution should direct research to... EFFECTS: I see research in my institution

having an effect on ...

$M(S D)$

\begin{tabular}{|c|c|c|c|c|c|c|}
\hline \multirow[t]{2}{*}{ naveng } & \multicolumn{3}{|c|}{$T A S K S$} & \multicolumn{3}{|c|}{ EFFECTS } \\
\hline & $\begin{array}{c}\text { Total } \\
\text { perception }\end{array}$ & $\begin{array}{l}\text { Perception } \\
\text { of lecturers }\end{array}$ & $\begin{array}{l}\text { Perception } \\
\text { of managers }\end{array}$ & $\begin{array}{c}\text { Total } \\
\text { perception }\end{array}$ & $\begin{array}{l}\text { Perception } \\
\text { of lecturers }\end{array}$ & $\begin{array}{l}\text { Perception } \\
\text { of managers }\end{array}$ \\
\hline External scale & $3.2(0.58)$ & $3.2(0.59)$ & $3.4(0.49)$ & $2.7(0.70)$ & $2.6(0.71)$ & $2.9(0.58)$ \\
\hline Enlarge external orientation of the institution & $3.3(0.76)$ & $3.2(0.78)$ & $3.5(0.64)$ & $2.8(0.82)$ & $2.7(0.84)$ & $3.0(0.73)$ \\
\hline Help companies and public organisations innovate & $3.2(0.80)$ & $3.1(0.81)$ & $3.4(0.67)$ & $2.5(0.83)$ & $2.5(0.84)$ & $2.9(0.73)$ \\
\hline Improve position of institution in society & $3.1(0.85)$ & $3.0(0.87)$ & $3.3(0.69)$ & $2.6(0.81)$ & $2.5(0.83)$ & $2.8(0.70)$ \\
\hline Solve practical issues of professional practice & $3.5(0.69)$ & $3.5(0.71)$ & $3.6(0.61)$ & $2.7(0.85)$ & $2.7(0.87)$ & $3.0(0.70)$ \\
\hline Theoretical scale & $3.2(0.62)$ & $3.1(0.63)$ & $3.3(0.55)$ & $2.4(0.71)$ & $2.4(0.72)$ & $2.5(0.63)$ \\
\hline Create new knowledge & $3.4(0.75)$ & $3.3(0.76)$ & $3.5(0.66)$ & $2.6(0.84)$ & $2.5(0.85)$ & $2.8(0.77)$ \\
\hline Develop new theories & $2.9(0.92)$ & $2.9(0.94)$ & $2.9(0.84)$ & $2.2(0.86)$ & $2.2(0.88)$ & $2.2(0.79)$ \\
\hline Deliver good researchers from UAS & $3.0(0.89)$ & $2.9(0.90)$ & $3.1(0.81)$ & $2.4(0.84)$ & $2.3(0.85)$ & $2.4(0.76)$ \\
\hline Bring new knowledge to education & $3.4(0.68)$ & $3.4(0.70)$ & $3.6(0.60)$ & $2.6(0.85)$ & $2.5(0.87)$ & $2.7(0.78)$ \\
\hline Educational scale & $3.5(0.58)$ & $3.5(0.59)$ & $3.6(0.52)$ & $2.6(0.80)$ & $2.6(0.82)$ & $2.8(0.70)$ \\
\hline Improve the quality of education & $3.6(0.61)$ & $3.6(0.62)$ & $3.7(0.56)$ & $2.6(0.85)$ & $2.5(0.87)$ & $2.7(0.75)$ \\
\hline Improve the level of the teaching staff & $3.4(0.70)$ & $3.4(0.72)$ & $3.5(0.60)$ & $2.7(0.86)$ & $2.6(0.88)$ & $2.8(0.76)$ \\
\hline
\end{tabular}

$N=1826$, lecturers' $n=1435$. 
tasks and to the scale of theoretical effects. A single item indicates whether the respondents feel research activities in general belong at the hogescholen (Likert-4).

Further, the researchers requested personal variables such as gender, the name of the institution, the highest educational degree (Ph.D., university level, higher professional education, middle-level professional education), and the main task of the respondent (teaching, staff, management, lecturer, or other).

\section{Analysis}

First, the results for each of the separate items and for the scales are described (means, standard deviations) for lecturers and managers. The order of importance between the scales on tasks and the scales on effects will be tested by Student's $t$-test for teachers and managers separately. The preferences of teachers and managers will be compared in several ANCOVAs, in which the scales are separately used as dependent variables and 'being a teacher or not' is used as an independent variable. Gender, the institution of employment, and educational level are used as covariates. All analyses were conducted using SPSS18. Due to the unbalanced design with different $n$ for lecturers and managers, SSTYPE1 is used. A more conservative probability level of $\alpha=0.01$ will be used to avoid the risk of the Family Wise Error Rate (Tabachnick and Fidell, 2007).

\section{Findings}

\section{Research-related aims}

Most of the managers $(79 \%)$ and more than half of the lecturers state $(63 \%)$ that research, in their perception, indeed belongs at the hogescholen (scoring 3 or 4). An ANCOVA procedure shows that managers (3.1) have a more positive perception of the presence of research at the hogescholen than lecturers $(2.8),[F(1)=33.66$ and $p<0.000]$. On average, lecturers' mean scores for the different items on aims range from 2.9 to 3.6 (4-point Likert scale). Lecturers score highest on 'to improve the level of education', while 'to develop new theories' and 'to deliver good researchers from UAS' scored lowest (for all descriptives, see Table 1). For managers, the task 'to develop new theories' on average scores the lowest (2.9) and 'improve the level of education' scores the highest (3.7). On all items, the managers score higher than lecturers, except for the item 'to develop new theories'.

\section{Effects of research activities}

When looking at the effects perceived for each of these tasks, all scores are lower than the scores for the importance of aims. The effect of research 
D.M.E. (Didi) Griffioen and U. (Uulkje) de Jong

Academic Drift in Dutch Non-University Higher Education Evaluated

12

activities on the 'development of new theories' scores the lowest among lecturers as well as managers (both 2.2). Lecturers score the effects of research activities 'to enlarge external orientation of the institution' and 'solving practical issues of professional practice' highest (both 2.7). Managers perceive the effects on the same aspects as the highest (both scoring 3.0).

Again, the scores of the managers are higher for all aspects than those of the lecturers, except for the mutual lowest score. Further, for both aims and effects, the standard deviation among the managers is smaller for all items than the standard deviation among the lecturers, which shows the managers score more equally among themselves.

\section{Ordering in the perception of tasks}

When the aims are grouped in scales, a paired Student's $t$-test shows that the lecturers score the educational aims higher than external tasks $[t(1432)=16.61$; $p<0.000]$, and external tasks higher than theoretical tasks $[t(1432)=3.89$; $p<0.000]$. The managers score the aims in the same order, with educational tasks scoring higher than external aims $[t(390)=5.72 ; p<0.000]$, and external aims scoring higher than theoretical aims $[t(390)=7.14 ; p<0.000]$. Although the ordering of both lecturers and managers is similar, the scores of the managers are higher on all three scales, ranging from 3.3 to 3.6, while the lecturers have a mean score ranging from 3.1 to 3.5 .

\section{Ordering in perception of effects}

The lecturers (range 2.4-2.6) score on average somewhat lower on each scale than the managers (range 2.5-2.8). The perceived effects of research activities show that the lecturers see no difference between educational effects and external effects $[t(1432)=2.22 ; p=0.027(\mathrm{~ns})]$. Both the educational effects $[t(390)=9.17 ; p<0.000]$ and external effects $[t(390)=14.04 ; p<0.000]$ score higher than the theoretical effects. The managers score the external effects of research activities higher than the educational effects $[t(390)=3.99 ; p<0.000]$. The theoretical effects also receive lower scores than the educational effects $[t(390)=9.17 ; p<0.000]$.

\section{Perception of lecturers vs perception of managers on aims}

The perceptions of the lecturers and managers regarding different aims and effects are tested in an ANCOVA procedure and controlled for gender, educational level, and institution (for the full model and results on all modelled variables, see Table 2). The managers score each type of aim for research higher than the lecturers do, with $F(1)=37.67$ and $p<0.000$ for external tasks, 
D.M.E. (Didi) Griffioen and U. (Uulkje) de Jong Academic Drift in Dutch Non-University Higher Education Evaluated

Table 2 Differences between managers and lecturers; all parameters in the model results

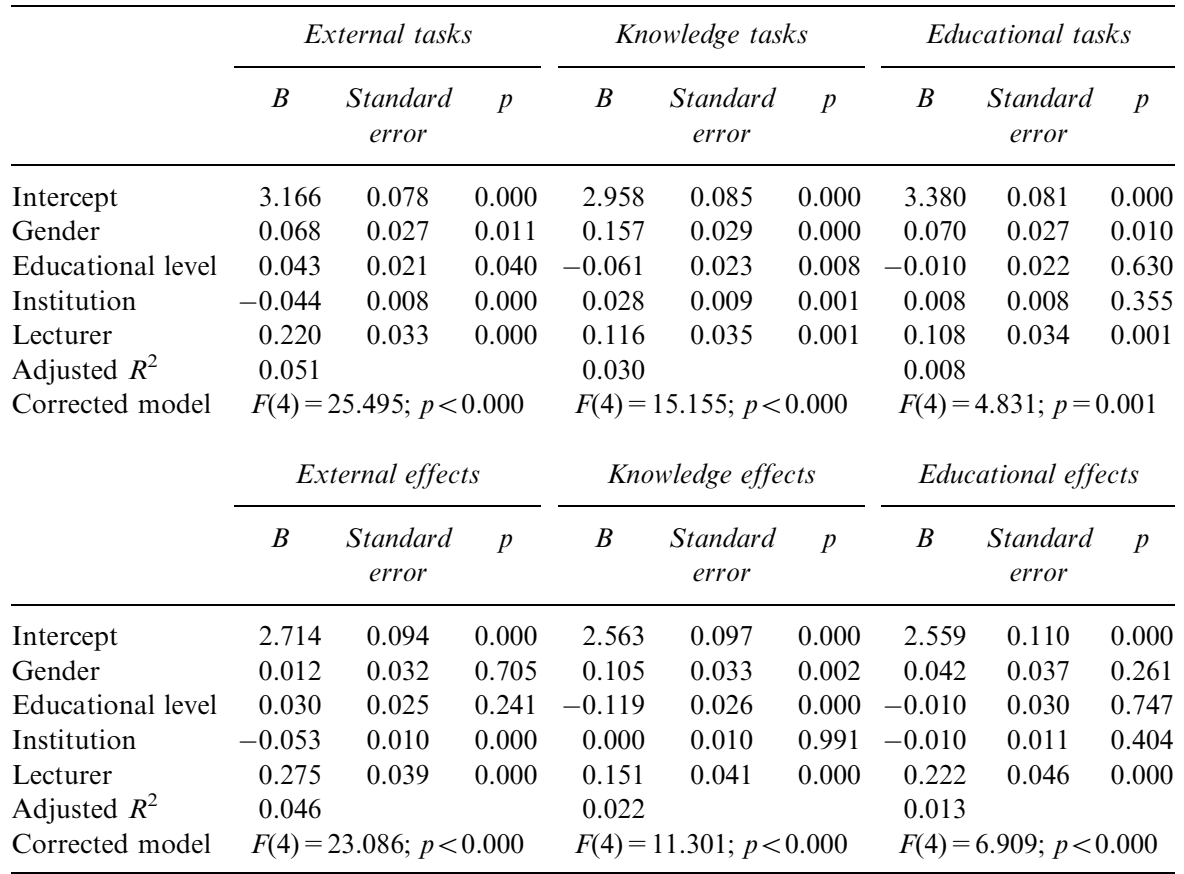

$N=1826$, lecturers' $n=1435$.

$F(1)=10.85$ and $p=0.001$ for knowledge tasks, and $F(1)=10.41$ and $p=0.001$ for educational tasks.

\section{Differences in perceived effects}

The managers perceive larger effects on all types of aims for research than do the lecturers, with $F(1)=49.03$ and $p<0.000$ for external effects, $F(1)=13.89$ and $p<0.000$ for knowledge effects, and $F(1)=23.39$ and $p<0.000$ for educational effects (for all results, see Table 2).

\section{Differences in extreme scores}

After finding the differences between the managers and lecturers, as described previously, it became interesting to test additionally (post hoc) whether the lecturers and managers score differently on the extremes, particularly how often respondents score high (4) on the items of the different scales. This frequency indicates a higher or lower aspiration towards each of the aims, depending on the scale. A Pearson's $\chi^{2}$ analysis shows that the managers more 
often have high aspiration with respect to external tasks $\left[X^{2}(4)=43.96\right.$; $p<0.000]$, and to theoretical tasks $\left[X^{2}(4)=18.82 ; p=0.001\right]$. There is no difference between lecturers and managers in scoring highly on educational tasks $\left[X^{2}(2)=8.60 ; p=0.014(\mathrm{~ns})\right]$.

\section{Conclusion}

Traditional universities in the Netherlands show a territorial attitude towards the research activities at the Dutch hogescholen (Griffioen and de Jong, 2007). This study investigates the perceptions of lecturers and managers to empirically evaluate indications of the intention for academic drift and actual academic drift at the staff level. The combined results show there is a moderate indication of potential for academic drift and of actual academic drift.

In general, both lecturers and managers are positive about research belonging at the hogescholen, although managers are significantly more positive. Nevertheless, thinking that research activities belong at the hogescholen, as such, does not necessarily indicate academic drift since the direction of research activities (being 'more practical' or 'more scientific') is not specified.

When the aims of research activities are considered, both lecturers and managers consider all three organisational aims for research (increasing quality of education, adding to the theoretical body of knowledge, and innovating in the professional field) important. In the ranking of the scale averages, the educational aims receive the highest place, followed by the aim of innovating in the professional field; the theoretical aim scores lowest. Thus, a moderate indication of potential for academic drift can be seen, since all aims received positive scores, including the more 'scientific' theoretical aim. However, education was and is still the main aim of the hogescholen in the eyes of both lecturers and managers.

Lecturers and managers have less uniform perceptions of effects of research activities. The managers perceive a larger extension than do lecturers of the traditional teaching aims towards innovating in the professional field through research.

Since there is no difference in how the lecturers perceive the research effects on educational quality or external innovation, one can say that this equality also indicates an extension of the teaching aim. Previously, nonuniversity institutions acted mostly as teaching institutions only. Innovating the professional field was only done by educating new professionals, and the institutions previously did not aim for innovation by research, since research activities as such were first introduced to get the educational programmes at least up-to-date (Advisory Council for Science and Technology Policy, 2005). So, the positive score of lecturers on the perceived effects of this aim can 
therefore be seen as an indication of change. Furthermore, at best, a small indication of actual academic drift in the perceived effects of research activities can be seen with all theoretical aspects scoring around the midpoint of the scale (2.4-2.9).

When the number of high scores is considered, managers tend to score more positively on items concerning external aims as well as on items concerning theoretical aims, hence managers more often show potential of academic drift. Also, a larger group of managers than lecturers find it important to strive for a role in helping to innovate in the professional field by research activities. These results are in line with previous research in which managers were more optimistic than lecturers regarding goals for innovation in education (Peterson and White, 1992; van den Berg and Sleegers, 1996; McRoy and Gibbs, 2009).

Finally, striving to achieve the activities and status of traditional universities is considered central in academic drift (Neave, 1979; Edwards and Miller, 2008; Harwood, 2010; Christensen and Erno-Kjolhede, 2011). When the results of this study are considered, a moderate indication of potential for staff drift has been found for both lecturers and managers of Dutch hogescholen. Managers are more positive on all aspects and show more potential for academic drift than do lecturers, but both groups consider education to be their main activity when aims for research are considered.

\section{Limitations and implications for practice}

In this study, academic drift is reduced to staff drift, one of the six academic processes in which academic drift can take place, as defined by Kyvik (2007). With respect to staff drift, this study is particularly interested in the perceptions of lecturers and managers, which has limitations when compared with actual activities being measured. Therefore, further research should include the measurement of actual research activities, as well as the individual preferences of lecturers for research and/or teaching as part of the construct of staff drift. Aspects of the other five processes of drift should also be studied. The limitation of the current study to processes of staff drift asks for further research in the Netherlands and other parts of Europe on the other five processes of academic drift to fully describe and understand the process of academic drift in non-university institutions.

The implications for practice are twofold: First, when further implementation of research activities is considered, it would be wise to connect research activities explicitly to the improvement of educational activities, because education is perceived to be the most important activity of non-university higher education and also as the most important outcome of their research activities. Even though these institutions are increasingly striving for the explicit connection between research and teaching, it is no easy task. 
D.M.E. (Didi) Griffioen and U. (Uulkje) de Jong

Academic Drift in Dutch Non-University Higher Education Evaluated

16

Organisational structures have mostly started out with separate structures for research and teaching, and only small groups of lecturers are nowadays actually involved in research activities (Dutch Ministry of Education Culture and Science, 2011). Connective experiences as well as organisational structures have yet to be built. The non-university institutions should learn from the body of knowledge on the connection between research and teaching (and its limitations) in the traditional universities (Healey, 2005; Barnett, 2006; Elsen et al., 2008; Verburgh et al., 2009; Brew, 2010).

Second, when the non-university institutions are actually directing their research aims towards improving educational practices, this can also be of interest for the traditional universities, who have a long research tradition but sometimes a less explicit developed tradition in teaching and didactics than the hogescholen do. By exchanging these kinds of research and teaching experiences, both types of institutions could improve their practices. For the nonuniversity institutions, a possible additional result can be to develop their own research culture (Griffioen and Boei, 2010; Boei and Griffioen, 2011).

\section{Acknowledgments}

We would very much like to thank the reviewers for their advice on how to adjust this article.

\section{Note}

1 This study uses hogescholen and institutions of non-university higher education to name these institutions. 'Vocational' and 'professional' will be used to describe the type of education.

\section{References}

Advisory Council for Science and Technology Policy. (2005) Ontwerp en ontwikkeling. De functie en plaats van onderzoeksactiviteiten in hogescholen, The Hague: Advisory Council for Science and Technology Policy.

Baggen, P. (2005) 'De wereld veranderen: universiteit en overheidsbeleid in Nederland, 1960-2000', in L.J. Dorsman and P. Knegtmans (eds.) Universitaire vormingsidealen. De Nederlandse universiteiten sedert 1876, Hilversum: Verloren, pp. 93-108.

Barnett, R. (ed.) (2006) Reshaping the University. New Relationships between Research, Scholarship and Teaching, Berkshire/New York: Open University Press.

Beijaard, D., Meijer, P.C. and Verloop, N. (2004) 'Reconsidering research on teacher's professional identity', Teaching and Teacher Education 20(2): 107-128.

Boei, F. and Griffioen, D.M.E. (2011) 'Promoveren in het Hoger Beroepsonderwijs: een verkenning, Onderzoek van Onderwijs', Vakblad voor docenten in het Hoger Onderwijs 40(1): 4-9.

Boerma, K., Griffioen, D.M.E. and de Jong, U. (2011) 'The Executive's Standard on Research Competence of Teachers in Dutch non-university Higher Education', Proceedings of the 
Conference of the European Association for Research on Learning and Instruction (EARLI); 30 August-3 September 2011, Exeter, United Kingdom.

Brew, A. (2010) 'Transforming academic practice through scholarship', International Journal for Academic Development 15(2): 105-116.

Christensen, S.H. and Erno-Kjolhede, E. (2011) 'Academic drift in Danish professional engineering education. Myth or reality? Opportunity or threat?' European Journal of Engineering Education 36(3): 285-299.

de Boer, H.F., Enders, J. and Leisyte, L. (2007) 'Public sector reform in Dutch higher education: The organisational transformation of the university', Public Administration 85(1): $27-46$.

de Jong, H. and de Jager, G. (2007) 'Van hogeschool naar kennisorganisatie. Investeren in professionals', THEMA 7(3): 25-28.

de Weert, E. and Leijnse, F. (2010) 'Practice-oriented Research: The Extended Function of Dutch Universities of Applied Science', in S. Kyvik and B. Lepori (eds.) The Research Mission of Higher Education Institutions Outside the University Sector. Striving for Differentiation, London: Springer, pp. 199-218.

Dijstelbloem, H. and Schuyt, C.J.M. (2003) 'Kennismaken: nieuw overheidsbeleid voor de kennissamenleving', Bestuurskunde 12(4): 152-159.

Dutch Ministry of Education Culture and Science. (2011) Kwaliteit in Verscheidenheid. Strategische Agenda Hoger Onderwijs, Onderzoek en Wetenschap, The Hague: Dutch Ministry of Education Culture and Science.

Dutch Ministry of Education Culture and Science and Netherlands Association of Universities of Applied Sciences. (2001) Convenant Lectoren en Kenniskringen in het hoger beroepsonderwijs, The Hague: Dutch Ministry of Education Culture and Science, and Netherlands Association of Universities of Applied Sciences.

Duursma, M. (2005) 'Hogescholen schurken tegen universiteiten aan', NRC, 8 June, NRC Handelsblad, Amsterdam.

Edwards, R. and Miller, K. (2008) 'Academic drift in vocational qualifications? Explorations through the lens of literacy', Journal of Vocational Education and Training 60(2): 123-131.

Elsen, M., Visser-Wijnveen, G.J., Van der Rijst, R.M. and Van Driel, J.H. (2008) 'How to strengthen the connection between research and teaching in undergraduate university education', Higher Education Quarterly 63(1): 64-85.

Geijsel, F., Sleegers, P., Van den Berg, R. and Kelchtermans, G. (2001) 'Conditions fostering the implementation of large-scale innovation programs in schools: teachers' perspectives', Education Administration Quarterly 37(1): 130-166.

Griffioen, D.M.E. and Boei, F. (2010) 'Promoveren in het hoger beroepsonderwijs: een stand van zaken', THEMA 12(5): 4-9.

Griffioen, D.M.E. and De Jong, U. (2007) 'De positie van onderzoek in het HBO; geschiedenis van een discussie', Proceedings of the Onderwijs Research Dagen; 6-8 June; Groningen, the Netherlands.

Griffioen, D.M.E., De Jong, U. and Jak, S. (2013) 'Research self-efficacy of lecturers in nonuniversity higher education', Innovation in Education and Teaching International, 50(1).

Harwood, J. (2010) 'Understanding academic drift: on the institutional dynamics of higher technical and professional education', Minerva 48(4): 413-427.

Healey, M. (2005) 'Linking Research and Teaching: Exploring Disciplinary Spaces and the Role of Inquiry-based Learning', in R. Barnett (ed.) Reshaping the University: New Relationships between Research, Scholarship and Teaching, McGraw Hill: Open University Press, pp. $67-78$.

Hill, M.F. and Haigh, M.A. (2011) 'Creating a culture of research in teaching education: Learning research within communities of practice', Studies in Higher Education iFirst apublication 12 August. doi: 10.1080/03075079.2011.559222. 
D.M.E. (Didi) Griffioen and U. (Uulkje) de Jong

Academic Drift in Dutch Non-University Higher Education Evaluated

Huisman, J. (2008) 'Shifting Boundaries in Higher Education: Dutch Hogescholen on the Move', in J.S. Taylor, J. Brites Ferreira, M. De Lourdes Machado and R. Santiago (eds.) Non-University Higher Education in Europe, London: Springer, pp. 147-168.

Huisman, J. and Kaiser, F. (2001) Fixed and Fuzzy Boundaries in Higher Education. A Comparative Study of (binary) Structures in Nine Countries, The Hague: Advisory Council for Science and Technology Policy.

Kyvik, S. (2004) 'Structural changes in higher education systems in Western Europe', Higher Education in Europe 29(3): 393-409.

Kyvik, S. (2007) 'Academic Drift - A Reinterpretation', in The Officers and Crew of HMS Network (ed.) Towards a Cartography of Higher Education Policy Change. A Festschrift in Honour of Guy Neave, CHEPS: Enschede, pp. 333-338.

Kyvik, S. (2009) The Dynamics of Change in Higher Education, Dordrecht: Springer.

Kyvik, S. and Skodvin, O.-J. (2003) 'Research in non-university higher education sector - tensions and dilemmas', Higher Education 45(2): 203-222.

Leijnse, F. (2005a) 'Hogeschool is domein nieuwe kennis', De Volkskrant, 6 September.

Leijnse, F. (2005b) Hooggeleerde domheid en andere gebreken. Over kennisproductie in de polder, Utrecht: Hogeschool Utrecht.

Lepori, B. and Kyvik, S. (2010) 'The research mission of universities of applied sciences and the future configuration of higher education systems in Europe', Higher Education Policy 23(3): 295-316.

McRoy, I. and Gibbs, P. (2009) 'Leading change in higher education', Educational Management Administration and Leadership 37(5): 687-704.

Mudde, R.F. (2005) 'Dikdoenerij en mannetjesmakerij passen HBO niet', NRC, 11 August, NRC Handelsblad, Amsterdam.

Neave, G. (1978) 'Polytechnics: A policy drift?' Studies in Higher Education 3(1): 105-111.

Neave, G. (1979) 'Academic drift: Some views from Europe', Studies in Higher Education 4(2): 143-159.

Peterson, M.W. and White, T.W. (1992) 'Faculty and administrator perceptions of their environments: Different views or different models of organization?' Research in Higher Education 33(2): 177-204.

Runhaar, P. (2008) 'Promoting teachers' professional development', Ph.D. dissertation, University of Twente.

Rupp, J.C.C. (1997) Van oude en nieuwe universiteiten. De verdringing van Duitse door Amerikaanse invloeden op de wetenschapsbeoefening en het hoger onderwijs in Nederland, 1945-1995, Den Haag: Sdu Uitgevers.

Seyd, R. (2000) 'Breaking down barriers: The administrator and the academic', Perspectives: Policy and Practice in Higher Education 4(2): 35-37.

Tabachnick, B.G. and Fidell, L.S. (2007) Using Multivariate Statistics, Boston: Pearson.

Teichler, U. (2008) 'The End of Alternatives to Universities or New Opportunities?', in J.S. Taylor, J.B. Ferreira, M. De Lourdes Machado and R. Santiago (eds.) Non-University Higher Education in Europe, Dordrecht: Springer, pp. 1-14.

van den Berg, R. and Sleegers, P.J.C. (1996) 'Building Innovative Capacity and Leadership', in K. Leithwood (ed.) International Handbook of Educational Leadership and Administration, London: Springer.

van den Berg, R., Sleegers, P., Geijsel, F. and Vandenberghe, R. (2000) 'Implementation of an innovation: meeting the concerns of teachers', Studies in Educational Evaluation 26(4): 331-350.

van der Linden, W., Bakx, A., Ros, A., Beijaard, D. and Vermeulen, M. (2012) 'Student teachers' development of a positive attitude towards research and research knowledge and skills', European Journal of Teaching iFirst publication 23 January. doi: 10.1080/02619768.2011.643401. 
D.M.E. (Didi) Griffioen and U. (Uulkje) de Jong Academic Drift in Dutch Non-University Higher Education Evaluated

van Lieshout, H. and Borgdorff, H. (2005) 'Onderzoek onmisbaar in HBO' Hanzehogeschool, Groningen, (Unpublished).

Verburgh, A., Schouteden, W. and Elen, J. (2009) 'Onderzoek in het hoger onderwijs: onderzoeksbetrokken doelen in Vlaamse hogescholen', Onderzoek van Onderwijs. Vakblad voor docenten in het Hoger Onderwijs 28(3): 43-48.

Visser-Wijnveen, G.J., Van Driel, J.H., Van der Rijst, R.M., Verloop, N. and Visser, A. (2009) 'The relationship between academics' conceptions of knowledge, research and teaching A metaphor study', Teaching in Higher Education 14(6): 673-686.

VKO. (2010) 'Validatiecommissie Kwaliteitszorg Onderzoek', Kwaliteitszorg voor het onderzoek aan hogescholen, online publication, http://www.vkohogescholen.nl/, accessed February 2012.

Vogel, M.P. (2009) 'The professionalism of professors at German fachhochschulen', Studies in Higher Education 34(8): 873-888.

Witte, J., Van der Wende, M. and Huisman, J. (2008) 'Blurring boundaries: How the bologna process changes the relationship between university and non-university higher education in Germany, the Netherlands and France', Studies in Higher Education 33(3): 217-231. 